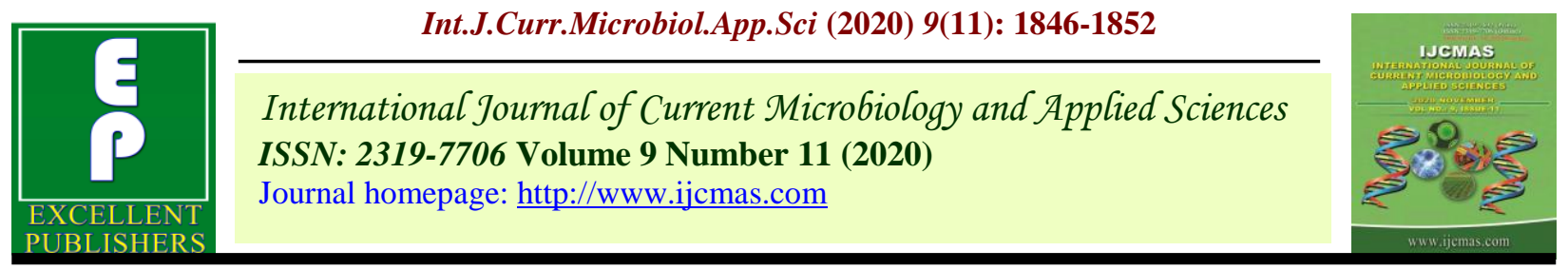

Original Research Article

https://doi.org/10.20546/ijcmas.2020.911.218

\title{
Response of Biofertilizers and Vermicompost on Growth, Flowering and Yield of Kombirei (Iris bakeri Wall.)
}

\author{
Koijam Koiremba, Rocky Thokchom* and Mabema Thongbam
}

Department of Horticulture, Pandit Deen Dayal Upadhyay Institute of Agricultural Sciences, Utlou, Bishnupur-795134, Manipur, India

*Corresponding author

\section{A B S T R A C T}

The present investigation was carried out at the Department of Horticulture, Pandit Deen Dayal Upadhyay Institute of Agricultural Sciences, Utlou,

Keywords

Kombirei,

Biofertilizers,

Vermicompost

Article Info

Accepted:

15 October 2020

Available Online:

10 November 2020 during 2018 - 2019. The experiment was conducted in Completely Randomized Design (CRD). Results indicated that application of vermicompost showed earliest sprouting of rhizomes ( 7.67 days) while the combined treatment consisting of vermicompost and biofertilizers viz., Azotobacter, PSB and VAM obtained maximum number of leaves per plant (18.33), plant height $(68.93 \mathrm{~cm})$, leaf width $(1.37 \mathrm{~cm})$, number of tillers (9.97), earliest spike emergence (187.74 days), days to flowering after spike emergence (8.05 days), number of spikes per plant (3.98), length of spike $(33.22 \mathrm{~cm})$, number of flowers per spike (4.68), spike durability at plant (11.57days). The same treatment yielded maximum number of spikes (35840/ha) as well as maximum weight of rhizomes per clump (97.03g).

\section{Introduction}

Kombirei (Iris bakeri Wall.) belonging to the family Iridaceae, is one of the most important Iris species closely associated with the history of Manipur. It is grown in the marshy areas of the valley districts of Manipur especially in Lamphelpat and Yaralpat wetlands. It is also one of India's newest Iris (flower) species. The flower is mainly lavender blue in colour with whitish strikes in the centre of the petals bearing about four to five florets in a spike. It has a flowering period of about 15 days in the first half of April every year. The leaves of kombirei are evergreen, sword-shaped and tall. The longevity of the spikes makes it one of the potent crops for cut flowers. Kombirei has a family of 80 genera (sub-family) with a total of 1870 species. According to research there are four species of Iris found in Manipur out of the country's 17 species as per Botanical Survey of India (CSIR, 2017) ${ }^{1}$. The 
other species are Iris singuinea, Iris watti and Iris kumaon. The difference between Iris bakeri and Iris singuinea besides the leaves is the presence of whitish strikes and heights of the flower. The plant is mainly used in its peak flowering time from March to May. It is generally used as an offering to the local deities and it is the main flower used in the new year of the Meitei community known as Cheiraoba. It is also used as cut flower. The flower extract can be used as dye and the rhizome has medicinal properties. It has been known that the rhizome of the plant can be used as a remedy by crushing it for decoction and is used as a brain coolant and in hysteria (Leishangthem and Sharma, 2014) ${ }^{2}$.

\section{Materials and Methods}

The present experiment was carried out on in the protected structure of the Department of Horticulture, Pandit Deen Dayal Upadhyay Institute of Agricultural Sciences, Utlou using polybags as the experimental pots during 2018- 2019. Planting materials were procured from Kombirei Garden, Yaralpat and the biofertilizers were obtained from Green Biotech, Imphal. The experiment was conducted in Completely Randomized Design (CRD) and considering one plant as one unit, with 10 treatments replicated thrice with 3 plants per replication. The details of different treatments are given below:

$\mathrm{T}_{1}$ - Control

$\mathrm{T}_{2-}$ Soil + Azotobacter (AZ)

$\mathrm{T}_{3}$-Soil + Vermicompost (V)

$\mathrm{T}_{4}$-Soil + Vesicular Arbuscular Mycorrhizae (VAM)

$\mathrm{T}_{5}$-Soil + Phosphate Solubilizing Bacteria (PSB)

$\mathrm{T}_{6}$-Soil + Azotobacter $(\mathrm{AZ})+$ Vermicompost (V)

$\mathrm{T}_{7}$-Soil + Azotobacter (AZ) + Vesicular Arbuscular Mycorrhizae (VAM)

$\mathrm{T}_{8}$-Soil + Azotobacter (AZ) + Phosphate
Solubilizing Bacteria (PSB)

$\mathrm{T}_{9}$-Soil + Azotobacter (AZ) + Vermicompost (V) + Vesicular Arbuscular Mycorrhizae (VAM)

$\mathrm{T}_{10}$-Soil + Azotobacter (AZ) + Vermicompost (V) + Vesicular Arbuscular Mycorrhizae $(\mathrm{VAM})+$ Phosphate Solubilizing Bacteria (PSB)

\section{Results and Discussion}

Biofertilizers are the substances containing living microorganisms which colonizes the rhizosphere or the interior parts of the plant, promote growth by increasing the supply or availability of primary nutrients to the target crops, when applied to the soils, seeds, or plant surface (Vessey, 2003) ${ }^{3}$. They are the natural fertilizers and are biologically active products containing certain strains of bacteria, algae or fungi, as a single or composite culture. They are known to produce plant hormones and anti-metabolites which promote root growth (Vithu et al., 2018) ${ }^{4}$. They not only give essential nutrients to the crop but also improve the physical characteristics of the soil and hence, it increases the yield of crops under continuous cropping system. Use of biofertilizers in crops has now become the matter of research which are eco-friendly and low in cost for the production of flower crops. The critically endangered Iris species locally known as Kombirei was chosen for the present experiment.

\section{Vegetative parameters}

The data from Table 1 revealed that the maximum number of leaves per plant (18.33), plant height $(68.93 \mathrm{~cm})$, leaf width $(1.37 \mathrm{~cm})$, number of tillers (9.97) were found higher in the treatment combination of biofertilizers along with vermicompost i.e., $\mathrm{T}_{10}$ (Azotobacter +Vermicompost + VAM +PSB), while earliest sprouting of rhizome was 
recorded in treatment $\mathrm{T}_{3}$ (Vermicompost). Least number of leaves per plant (9.90), plant height $(46.90 \mathrm{~cm})$, leaf width $(0.97 \mathrm{~cm})$, number of tillers(3.89), sprouting of rhizome (16.33 days) were recorded in the control treatment $\left(\mathrm{T}_{1}\right)$.

The reason may be due to the fact that the combined effects of Azotobacter, Vermicompost, PSB and VAM played a unique role in supplying essential nutrients in optimum quantity during growth period, thereby increasing photosynthates and their translocation towards vegetative organs and ultimately towards reproductive organs. Vermicompost contains macro and micro nutrients essential for growth and development of plants. Vermicompost is not only a good source of nitrogen, phosphate, potassium and micronutrients, but also helps in increasing soil organic matter and nutrient content by improving the soil structure and increase exchange capacity (Patel et al., $2017)^{5}$. The readily available nutrients in vermicompost may be the reason for early emergence of leaves of Iris plants. Phosphate solubilizing bacteria (PSB), Vesiculararbuscular mycorrhiza (VAM) and Azotobacter are known to produce growth promoting substances like Indole-3-acetic acid, gibberellin like substances, thiamine (Vitamin $\left.\mathrm{B}_{1}\right)$, riboflavin $\left(\mathrm{B}_{2}\right)$, Cobalamin (Vitamin $\mathrm{B}_{12}$ ) etc. (Wange and Patil, 1994) ${ }^{6}$. Phosphobacteria enhance the cell division and cell enlargement besides producing the plant growth hormones (Narasimha and Haripriya, $2001)^{7}$ which ultimately enhance the growth of the plant. Phosphate solubilizing bacteria also helps in the secretion of some organic acids such as lactic glycolic, fumaric and succinic acid that converts insoluble phosphate of soil into soluble form (Asokan et al., 2000) ${ }^{8}$. Addition of VAM fungi in the potting media also helps in increasing the amount of phosphorus with increase in age of the plant (Ojha et al., 2008) ${ }^{9}$. VAM fungi produces external hyphae which reach beyond the depletion zone around the root hair and absorbs soil phosphorous (P). It helps in translocation, perhaps in the form of polyphosphate granules, to the arbuscules where $\mathrm{P}$ is transferred to the pant cell in exchange of carbon (Mago and Mukherji, $2003)^{10}$.

\section{Floral and yield parameters}

Data pertaining to Table 2 shows that earliest spike emergence (187.74 days), minimum number of days taken for flowering (8.05 days), maximum number of spike per plant (3.98), maximum spike length $(33.22 \mathrm{~cm})$, maximum number of flower per spike (4.68), spike durability at plants (11.57 days), maximum yield of spikes/ha (35840) and weight of rhizomes per clump (97.03g) was recorded in treatment $\mathrm{T}_{10}$ (Azotobacter + Vermicompost + PSB +VAM). Control treatment recorded the least performances in all the cases.

Superiority in floral and yield parameters of Kombirei when treated with vermicompost and biofertilizers may be due to the good treatment combinations by which optimum doses of biofertilizers and organic compost are supplied to the plants.

Maximum weight of rhizomes per clump with the same treatment combination may be because of rapid vegetative growth, which resulted in increased fresh and dry matter production and partitioning to the developing rhizomes. Better nitrogen fixation and increased absorption of nitrogen under Azotobacter treatment, greater solublization of insoluble $\mathrm{P}$ and factors such as release of growth promoting substances, control of plant pathogens and proliferation of beneficial organisms in rhizosphere and internal parts of the plant because of PSB and VAM. 
Table.1 Effects of biofertilizers on vegetative growth of Kombirei

\begin{tabular}{|c|c|c|c|c|c|}
\hline Treatments & $\begin{array}{l}\text { Days to } \\
\text { sprouting }\end{array}$ & $\begin{array}{c}\text { Plant } \\
\text { Height }(\mathrm{cm})\end{array}$ & No. of leaves & Leaf width(cm) & No. of tillers \\
\hline $\mathrm{T}_{1}(\mathrm{CONTROL})$ & 16.33 & 46.90 & 9.90 & 0.97 & 3.89 \\
\hline $\mathbf{T}_{2}(\mathrm{AZ})$ & 10.67 & 53.17 & 11.47 & 1.03 & 6.66 \\
\hline $\mathbf{T}_{\mathbf{3}}(\mathbf{V})$ & 7.67 & 54.50 & 17.67 & 1.17 & 7.62 \\
\hline $\mathbf{T}_{4}(\mathrm{VAM})$ & 8.00 & 55.07 & 13.17 & 1.07 & 7.46 \\
\hline $\mathrm{T}_{5}(\mathrm{PSB})$ & 10.00 & 53.87 & 14.87 & 1.00 & 5.60 \\
\hline$T_{6}(A Z+V)$ & 10.33 & 59.80 & 14.10 & 1.13 & 7.28 \\
\hline$T_{7}(A Z+V A M)$ & 9.33 & 59.03 & 13.10 & 1.10 & 7.50 \\
\hline $\mathrm{T}_{8}(\mathrm{AZ}+\mathrm{PSB})$ & 9.00 & 56.90 & 14.33 & 1.07 & 7.49 \\
\hline$T_{9}(A Z+V+V A M)$ & 10.00 & 65.77 & 15.67 & 1.23 & 8.64 \\
\hline $\mathrm{T}_{10}(\mathrm{AZ}+\mathrm{V}+\mathrm{VAM}+\mathrm{PSB})$ & 10.00 & 68.93 & 18.33 & 1.37 & 9.97 \\
\hline $\operatorname{S.Ed}( \pm)$ & 2.02 & 3.93 & 1.80 & 0.11 & 0.44 \\
\hline C.D.(0.05\%) & 4.21 & 8.20 & 3.76 & 0.23 & 0.92 \\
\hline
\end{tabular}


Table.2 Effects of biofertilizers on floral and yield parameters of Kombirei

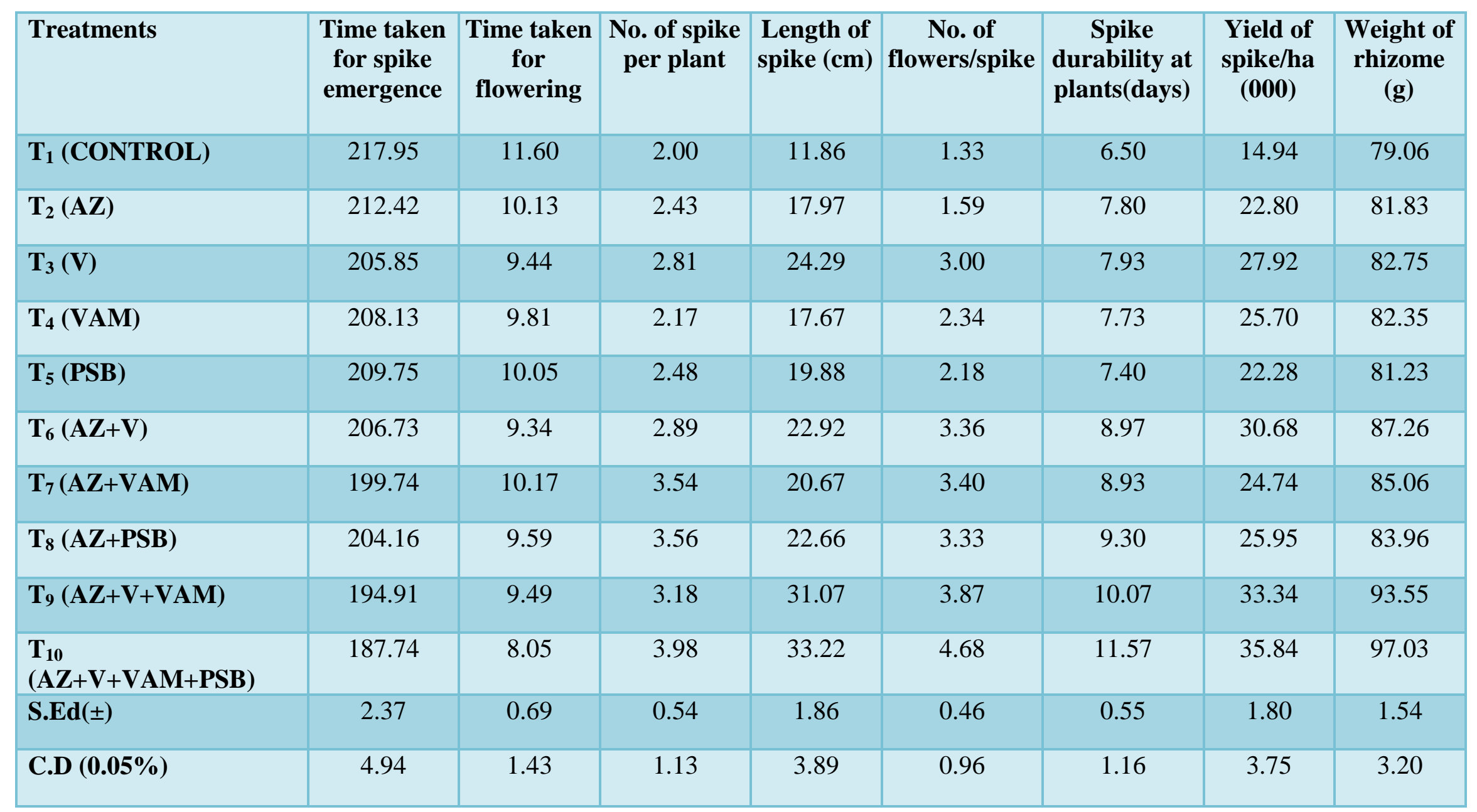


Continuous supply of macro and micro nutrients by vermicompost maintained vegetative growth which leads to better production of photosynthates thereby increasing the accumulation of assimilates and later partitioning to the developing rhizomes. Singh et al., (2008) ${ }^{11}$ observed that application of Azotobacter along with PSB and $75 \% \mathrm{~N} / \mathrm{ha}$ found better results with respect to plant growth, maximum fresh flower production and extended the flowering duration in calendula. Combined application of PSB, Azotobacter and Azospirillum produced maximum plant height, number of branches, flower size when compared to single application of those biofertilizers and control of African marigold cv. Pusa Narangi Gainda (Mathew and Singh, 2003) ${ }^{12}$. Radhika et al., $(2010)^{13}$ also found better vegetative and floral growth of African marigold when $70 \%$ RDF, 3 t/ha vermicompost, Azotobacter, Azospirillium and PSB when applied together.

From the result of one year pot experimentation, it can be concluded that combined use of biofertilizers played a significant role in vegetative growth, flowering and yield of Kombirei. Combined application of vermicompost along with different biofertilizers such as Azotobacter, PSB, and VAM can be used for kombirei production as the combined treatment gave maximum results in term of growth and yield of the crop. Even from economic point of view, combined use of biofertilizers is recommended for better return. But for recommendation to the farmers, further trial is needed for reconfirmation.

\section{References}

1. CSIR (2017). A daily news bulletin produced by Unit for Science Dissemination, CSIR, Anusandhan Bhawan, 2 Rafi Marg, New Delhi.
2. Leishangthem, S. and Sharma, L.D (2014). Study of some important medicinal plants found in Imphal East District, Manipur, India. Intl. J. Sci. and Res. Publications., 4(9): 2250-3153.

3. Vessey, J. K. (2003). Plant growth promoting rhizobacteria as biofertilizers. Plant Soil, 255(2): 571-586.

4. Vithu, G. N., Varu, D. K., Patel, D. and Aghera, S. R. (2018). Efficacy of biofertilizers to improve flower production. Bull. Env. Pharmacol. Life Sci., 8(1): 9-17.

5. Patel, V.S., Malam, V.R., Nurbhanej, K.H., Vihol, A.N. and Chavada, J.R. (2017). Effect of organic manures and biofertilizers on growth, flowering and flower yield of rose (Rosa hybrida L.) cv. Gladiator Intl. J. Chem. Studies, 5(5): 1924-1927.

6. Wange, S. S. and Patil, P. L. (1994). Response of tuberose to biofertilizers and nitrogen. J. Maharashtra Agril. Univ., 19: 484-485.

7. Narasimha, S. and Haripriya, K. (2001). Integrated nutrient management in crossandra cv. Dindigul Local. South Indian Hort., 49(1-6): 181-184.

8. Asokan, R., Sukhada, M. and Lalitha, A. (2000). Biofertilzers and biopesticides for horticultural crops. Indian Hort., 45(1): 44-47.

9. Ojha, S., Chakraborty, M.R., Dutta, M.R. and Chatterjee, N.C. (2008). Influence of VAM on Nutrient Uptake and Growth of Custard-apple. Asian J. Exp. Sci., 22(3): 221-224.

10. Mago, P. and Mukerji, K.G. (2003). Mycorrhizal technology in forestry and agriculture. In: Compendium of Mycorrhizal Research Vol II: Role of Mycorrhiza in biotechnology, (ds. K.G. Mukerji and B.P. Chamola), A.P.H. Publishing Corporation, New Delhi. pp. 129146.

11. Singh, Y. P., Dwivedi, R. and Dwivedi, 
S. V. (2008). Effect of bio-fertilizer and graded dose of nitrogen on growth and flower yield of calendula (Calendula officinalis L.). Plant Archives, 8(2): 957958.

12. Mathew, B. and Singh, B. P. (2003). Effect of different combination of biofertilizers on growth and yield of African marigold (Tagetes erecta L.) cv. Pusa Narangi. In: National Symposium on recent Advances in Indian
Floriculture, Nov. 12-14, Abstracts. P. K. Rajeevan et. al. (eds), ICAR, New Delhi, I p.

13. Radhika, M., Patel, H. C., Nayee, D. D. and Sitapara, H. H. (2010). Effect of integrated nutrient management on growth and yield of African marigold (Tagetes erecta L.) cv. Local under middle Gujarat agro climatic condition. Asian J. Hort., 5(2): 347-349.

\section{How to cite this article:}

Koijam Koiremba, Rocky Thokchom and Mabema Thongbam. 2020. Response of Biofertilizers and Vermicompost on Growth, Flowering and Yield of Kombirei (Iris bakeri Wall.). Int.J.Curr.Microbiol.App.Sci. 9(11): 1846-1852.

doi: https://doi.org/10.20546/ijcmas.2020.911.218 